\title{
Representative estimates of soil and ecosystem respiration in an old beech forest
}

\author{
Alexander Knohl • Astrid R. B. Søe • \\ Werner L. Kutsch • Mathias Göckede • \\ Nina Buchmann
}

Received: 3 August 2007 / Accepted: 25 October 2007 / Published online: 23 November 2007

(C) Springer Science + Business Media B.V. 2007

\begin{abstract}
Respiration has been proposed to be the main determinant of the carbon balance in European forests and is thus essential for our understanding of the carbon cycle. However, the choice of experimental design strongly affects estimates of annual respiration and of the contribution of soil respiration to total ecosystem respiration. In a detailed study of ecosystem and soil respiration fluxes in an old unmanaged deciduous forest in Central Germany over 3 years (2000-2002), we combined soil chamber and eddy
\end{abstract}

Responsible editor Per Ambus

A. Knohl • A. R. B. Søe • W. L. Kutsch

Max Planck Institute for Biogeochemistry,

Hans Knöll Str. 10,

07745 Jena, Germany

A. Knohl $(\bowtie) \cdot$ N. Buchmann

Institute of Plant Sciences, ETH Zürich,

Universitätstrasse 2, LFW C38,

CH-8092 Zürich, Switzerland

e-mail: alexander.knohl@ipw.agrl.ethz.ch

\section{A. R. B. Søe}

Fertin Pharma,

Dandyvej 19,

DK-7100 Vejle, Denmark

M. Göckede

Department of Forest Science, Oregon State University, Corvallis, OR 97331, USA covariance measurements to obtain a comprehensive picture of respiration in this forest. The closed portable chambers offered to investigate spatial variability of soil respiration and its controls while the eddy covariance system offered continuous measurements of ecosystem respiration. Over the year, both fluxes were mainly correlated with temperature. However, when soil moisture sank below 23 vol.\% in the upper $6 \mathrm{~cm}$, water limitations also became apparent. The temporal resolution of the eddy covariance system revealed that relatively high respiration rates occurred during budbreak due to increased metabolic activity and after leaf fall because of increased decomposition. Spatial variability in soil respiration rates was large and correlated with fine root biomass $\left(r^{2}=0.56\right)$ resulting in estimates of annual efflux varying across plots from 730 to 1,258 (mean 898) $\mathrm{g} \mathrm{C} \mathrm{m}^{-2}$ year $^{-1}$. Power function calculations showed that achieving a precision in the soil respiration estimate of $20 \%$ of the full population mean at a confidence level of $95 \%$, requires about eight sampling locations. Our results can be used as guidelines to improve the representativeness of soil respiration measurements by nested sampling designs, being applied in long-term and large-scale carbon sequestration projects such as FLUXNET and CarboEurope.

Keywords Carbon flux · Eddy covariance .

Footprint $\cdot$ Soil $\mathrm{CO}_{2}$ efflux - Sampling design .

Uncertainty analysis $\cdot$ Monte Carlo simulation 


\section{Introduction}

Respiration is one of the largest and most important carbon dioxide $\left(\mathrm{CO}_{2}\right)$ fluxes in terrestrial ecosystems (Valentini et al. 2000), with many components such as $\mathrm{CO}_{2}$ efflux from soil, leaves, stems, and branches. Soil respiration has been shown to make up 55-85\% of the whole ecosystem respiration in different forest types (Law et al. 1999; Pilegaard et al. 2001; Shibistova et al. 2002; Davidson et al. 2006). Because of growing concern about the global carbon budget, it is essential to understand how respiration fluxes contribute to the overall exchange of carbon between biosphere and atmosphere.

Ecosystem respiration and soil respiration are generally measured by very different techniques (normally measurements from a tower with the eddy covariance system for ecosystem respiration and chamber measurements for soil respiration) which integrate over very different spatial scales. While ecosystem respiration from the eddy covariance measurement integrate typically fluxes from a large area (on the order of about $1 \mathrm{~km}^{2}$ in the case of forests depending on atmospheric stratification), soil respiration from chamber measurement covers fractions of square meter. Linking soil respiration measurements to ecosystem respiration thus requires a good understanding of spatial variability of soil respiration and its controlling factors within the source area (footprint) of the flux measurements. In ecosystems with high spatial variability, portable chamber systems are well suited in the search for controlling factors of soil respiration since many spatial replications ensure the full coverage of this variability. However, nonautomated soil respiration systems are not well suited for assessing the temporal variability of soil respiration because of labor intensity. Here, continuously measuring soil respiration systems have major advantages (Davidson et al. 2006). Optimally, all three systems - portable soil respiration chambers, automated soil respiration chambers and eddy covariance measurements - would be employed to study temporal as well as spatial variations. All approaches, however, are prone to systematic biases: the eddy covariance technique by potentially underestimating night time fluxes under non-turbulent conditions (Goulden et al. 1996) and the chamber techniques by over- or underestimating soil respiration due to chamber effects (Hutchinson and Livingston 2002; Savage and Davidson 2003; Pumpanen et al. 2004).

When respiration is measured during campaigns, an adequate statistical model is necessary in order to reliably estimate the annual $\mathrm{CO}_{2}$ efflux. Moreover, when respiration is measured continuously (automated chamber or eddy covariance from a tower), statistical models are needed for gap filling and (at certain times) to extrapolate from night to day data. In temperate forest ecosystems with relatively high amounts of precipitation, soil temperature is typically the most important factor determining temporal variation in respiration rates (e.g. Davidson et al. 1998; Buchmann 2000). The most frequently used models for soil and ecosystem respiration are those that present a simple exponential relationship between soil temperature and respiration (e.g. Buchmann 2000) and an extended Arrhenius function (Lloyd and Taylor 1994). However, linear, power, and sigmoid functions have also been suggested in the literature (Janssens et al. 2003). Furthermore, in dry and even temperate and boreal - ecosystems, soil moisture can be just as important as soil temperature for soil respiration rates, and it may be that soil moisture has to be included in the respective model (Rey et al. 2002; Reichstein et al. 2003, Davidson et al. 1998, Pumpanen et al. 2003).

In a parallel study, Soe and Buchmann (2005) investigated on a $72 \times 72 \mathrm{~m}$ grid the influence of soil properties on spatial variability of soil respiration. Building on this work we wanted to asses how soil respiration measured along a transect within the source areas of a flux tower relates to ecosystem respiration. Furthermore, we aimed to investigate the effect of experimental design (e.g. number of samples) on the soil respiration flux estimates. To investigate these questions, we carried out a detailed study on soil and ecosystem respiration in an unmanaged deciduous forest in the National Park Hainich, Germany. The objectives of the study were (1) to determine the effect of spatial and temporal variability on annual estimates of respiration, and (2) to develop recommendations for the sampling strategy that best estimates annual soil respiration at a forest site with high spatial heterogeneity. 


\section{Materials and methods}

Site description and experimental layout

The study was carried at the tower site in the National Park Hainich $\left(51^{\circ} 05^{\prime} \mathrm{N}, 10^{\circ} 27^{\prime} \mathrm{E}, 440 \mathrm{~m}\right.$ a.s.l., Central Germany). The temperate deciduous forest has been protected as a National Park without any forest management since 1997. For 40 years before 1997, the forest was taken out of regular forest management because of its status as a military training area. Prior to this, the forest had been extensively managed. Nowadays, a broad range of tree ages ( 0 to 250 years) and a large proportion of woody debris characterize the forest (Knohl et al. 2003). The dense canopy consists of European beech (Fagus sylvatica L.) with scattered individuals of Fraxinus excelsior L., Acer pseudoplatanus L., A. platanoides L., A. campestre L. and Carpinus betulus L. The herbaceous understory vegetation flourishes before canopy budbreak. The soils are cambisols with a depth of 50 to $60 \mathrm{~cm}$ (clayrich layer with calcareous bedrock). The A-horizon is $10-15 \mathrm{~cm}$ deep $(\mathrm{pH}$ about 5, carbon content $6.5 \%$, and nitrogen content $0.5 \%$ ). The mineral soil is characterized by a large clay content $(40 \%$, sand $4 \%$ ). The litter from the forest trees and herbs decomposes almost totally within 1 year. The litter layer is thin (about $0.5 \mathrm{~cm}$ ) and clearly distinguishable from the A-horizon. For the period from 2000 to 2002 , the mean annual air temperature was $8.4^{\circ} \mathrm{C}$ and the precipitation per year was $899 \mathrm{~mm}$ (measurements made at the site, Knohl et al. 2003).

Soil respiration was measured within the main footprint (i.e., source area) of the flux measurement at the tower with a portable measurement system at 36 permanent locations (pre-installed soil collars) in 10 plots along a $300 \mathrm{~m}$ transect south-east of the eddy covariance tower. In each plot, three to five measurement collars were placed about $1 \mathrm{~m}$ from each other, and the distance between plots was $30 \mathrm{~m}$. From May 2000 through December 2002, soil respiration was measured every 2 to 6 weeks. Ecosystem respiration was measured continuously with the eddy covariance technique from a $43.5 \mathrm{~m}$ tall tower (about $10 \mathrm{~m}$ above the canopy, for details, see below or Knohl et al. 2003). The dominant wind direction $(70 \%$ of all times) was from the south-east (along the measure- ment transect). In order to assess the source area of measured ecosystem respiration we applied a footprint model built on the Thomson (1987) Lagrangian Stochastic trajectory model of Langevin type (e.g. Wilson et al. 1983), which is operated forward in time. The exact formulation of the footprint algorithms, the definition of the flow statistics and the effect of stability on the profiles is described in Rannik et al. (2003). For each model run, $5 \times 10^{4}$ particles were released from a height equal to 0.01 times the canopy height. A flux footprint can be derived by integrating their trajectories up to the upwind distance accounting for approximately $90 \%$ of the total flux. To facilitate footprint analyses based on 30-min averaged fluxes over longer time periods, source weight functions were pre-calculated for 18 classes of atmospheric stability (see Gockede et al. 2005 for details). We then calculated the average source weight function by combining the probability density function of measured atmospheric stability at the Hainich site with the footprint function associated with each stability class. In order to stay consistent with ecosystem respiration which is derived from nighttime measurements, we used the probability density function of atmospheric stability during nighttime for the footprint calculation. The source weight function peaked at approximately $210 \mathrm{~m}$ from the tower, and $50 \%$ of the integrated source weight function was reached at $365 \mathrm{~m}$.

\section{Measurements of respiration}

Soil respiration was measured with pre-installed soil collars (Soe and Buchmann 2005) using a portable infrared gas analyzer and a closed chamber system (LiCor 6400-09, LiCor, Inc., Lincoln, NE, USA; data were corrected for air humidity according to the LiCor-6400 manual). The collars consisted of PVC tubes about $10 \mathrm{~cm}$ in diameter and $7 \mathrm{~cm}$ high with stainless steel legs for stabilization. The collars were inserted to a depth of $1 \mathrm{~cm}$. Each soil respiration measurement was accompanied by measurements of temperature in the litter layer, and at three soil depths, at 5, 10, and $15 \mathrm{~cm}$ (LiCor 6400-09, LiCor, Inc., Lincoln, NE, USA), as well as soil moisture at $0-6 \mathrm{~cm}$ soil depth below the litter layer (ThetaProbe, ML-2x, DeltaT, Cambridge, UK). Each measurement campaign lasted one full day and was carried out during daytime. 
Ecosystem respiration was calculated from nighttime measurements of carbon dioxide mixing ratios and vertical wind speed at the top of the tower using the eddy covariance technique. The flux system consisted of a triaxial sonic anemomenter at the top of the tower (Gill Solent R3, Gill Instruments, Lymington, UK) and a closed-path fast response $\mathrm{CO}_{2} / \mathrm{H}_{2} \mathrm{O}$ infrared gas analyzer in absolute mode placed at ground level (LiCor 6262-3, LiCor Inc. Lincoln, NE, USA). Air was drawn through tubing from the inlet on the top of the tower to the gas analyzer at the bottom. Full details of the eddy covariance measurements and calculations are given in Knohl et al. (2003). In close proximity to the tower, soil temperature was measured at several depths $(2,5$, $15,30$, and $50 \mathrm{~cm})$ using PT-100-temperature sensors, and soil moisture at several depths $(5,15$, and $30 \mathrm{~cm})$ using ThetaProbes (ML-2x, DeltaT, Cambridge, UK). These data were collected every $10 \mathrm{~s}$ and stored as $10 \mathrm{~min}$. average values with data loggers (CR23x and CR10X, Campbell Scientific, Logan, UT, USA).

\section{Root analyses}

Two soil samples $(0-8 \mathrm{~cm}$ depth, diameter $=5 \mathrm{~cm})$ were collected in each of the 10 plots along the transect in June 2001, close to the permanent soil respiration measurement locations. Fine roots were extracted by washing the fresh soil samples with a set of sieves $(630 \mu \mathrm{m}$ and $2 \mathrm{~mm})$ to free roots from soil. Living fine roots (diameter smaller than $2 \mathrm{~mm}$ ) were dried $\left(70^{\circ} \mathrm{C}, 48 \mathrm{~h}\right)$ and weighed.

Statistical analyses and calculations

Mean values, standard deviations, regressions, and uncertainty analysis were calculated using the statistical software package SPlus 7.0 (Insightful Corporation, Seattle, WA, USA) and SigmaPlot 9.0 (Systat Software Inc., San Jose, CA, USA). Soil respiration was correlated with soil temperature using a simple exponential equation:

$R=k e^{a T}$,

where $R$ is soil respiration [ $\mu \mathrm{mol} \mathrm{CO}_{2} \mathrm{~m}^{-2} \mathrm{~s}^{-1}$ ], $T$ is soil temperature $(5 \mathrm{~cm})\left[{ }^{\circ} \mathrm{C}\right], k$ and $a$ are constants fitted by regression.

Because late summer 2001 was dry, soil respiration was significantly influenced by soil moisture content.
Therefore we included soil moisture in the model (Eq. 2):

$R=k e^{a T} e^{b \theta}$

where the parameters are the same as for Eq. 1, and, $\theta$ is soil moisture at $5 \mathrm{~cm}$ [vol.\%] and $b$ is another constant fitted by regression. We did not include effects of a potential decline in soil respiration at high soil moisture (Subke et al. 2003) since our data were too sparse to capture such an effect. Data from the whole year were used to calculate soil respiration estimates. Since measurements started only in May 2000 and therefore no winter data were available, we included the measurements made on 10 January 2001 also into the data set of 2000 . We used the discontinuous measurements of soil temperature and soil moisture done along with the soil respiration measurements at each collar to fit the regression parameters $k, a$, and $b$ of Eqs. 1 and 2. In order to calculate annual estimates of soil respiration we applied the collar specific regression function to continuous measurements of soil temperature and soil moisture (in case of Eq. 2) measured at the flux tower. Since soil temperature (and moisture) measurements were systematically lower at the tower (with permanently installed PT-100 temperature sensors and ThetaProbes) than at the collars (with the LiCor 6400 and a portable ThetaProbe), we corrected the continuous time series of soil temperature and moisture from the tower by linear regression to the portable measurements at the collars. This correction led to an increase in soil respiration estimate by about 7\% (70-100 g C m$^{-2}$ year $\left.^{-1}\right)$.

Uncertainty of annual sums in soil respiration due to spatial variability and to temporal integration to 1 year was assessed with Monte Carlo simulations (parametric bootstrapping, Crawley 2002). First, we calculated regressions according to Eq. 1 for each measurement collar $(N=36)$ yielding regression parameters ( $k$ and $a$ ) as well as estimated standard deviations of $k$ and $a$, and residual errors (see above). Second, we calculated 5,000 annual sums of soil respiration (based on the continuous soil temperature measurements) for each collar by sampling 5,000 times pairs of the parameters $k$ and $a$ with replacement from a bivariate normal distribution defined by the values and standard deviations of $k$ and $a$. Third, based on the distribution of annual soil respiration 
sums at each collar obtained from the 5,000 samplings, we calculated their means and statistical properties. To obtain mean and confidence intervals across several collars, e.g. in one plot, we averaged annual sums from each sampling across all collars at e.g. one plot and report means and 95\% confidence intervals of these average annual soil respiration rates. In order to avoid effects of spatially non-independent samples (see below) and unequal numbers of collars per plot we always first averaged across all collars at each plot and then across plots.

Additionally, in order to test the influence of the residual error on annual sums we (a) assumed a normal distribution of the residual error with a mean of zero and a standard deviation equal to the residual error. In this case, our analysis revealed that the residual error did not influence the estimated annual sum of soil respiration and its uncertainty. We then (b) assumed that the residual error was autocorrelated since soil respiration rates might show temperatureindependent variations over diurnal or seasonal cycles (e.g. Liu et al. 2006). For this case we simulated a random autocorrelated time series (resembling e.g. a temperature-independent diurnal or seasonal effect on soil respiration) for each drawing with a standard deviation equal the residual error. Since the degree of autocorrelation was not extractable from the measured data, we performed a sensitivity analysis for autocorrelations from 0 to 0.9 in 0.1 steps. This sensitivity analysis revealed that even a highly autocorrelated residual error (autocorrelation of 0.9 ) had only a negligible influence $(<0.5 \%)$ on the estimated annual sum of soil respiration and its uncertainty. Hence, the residual error was negligible for the annual sum of soil respiration.

For the case of Eq. 2 with three parameters (year 2001 only as a consequence of moisture limitations), there were not enough measurements available to perform a robust parametric bootstrap calculation. We therefore only reported mean annual soil respiration rates.

In order to compare different sampling designs we compare mean annual soil respiration rates taking into account only measurement collars close to the tower $(0-50 \mathrm{~m})$, across all plots $(0-300 \mathrm{~m})$ and weighted by the nighttime source weight function as calculated from the footprint model (see Table 2).

The number $(N)$ of respiration measurement locations needed for various degrees of precision in terms of spatial variability was calculated using a power function (Davidson et al. 2002):

$N=\left[\frac{t \cdot s}{\text { range } / 2}\right]^{2}$

where $t$ is the $t$-statistic (two-way test) for a given confidence level $(3.250,2.262,1.833,1.383$ for a confidence of $99,95,90,80 \%$, respectively) and degrees of freedom $(d f=9), s$ is the standard deviation of the full population of spatially independent measurements (all plots during 1 day), and range is the width of the desired interval around the full population mean in which a smaller sample mean is expected to fall $( \pm 10, \pm 20$ or $\pm 30 \%$ of mean). We first calculated $N$ for each individual day where measurements were made and then calculated an average $N$ for all 3 years with its standard error.

Ecosystem respiration was calculated from the nighttime flux measurements with the eddy covariance technique. Nighttime flux data were extrapolated to the entire year based on mean nighttime flux values and Eqs. 1 and 2 with continuous measurements of soil temperature and soil moisture. There is, however, a controversial discussion whether daytime respiration responds to temperature in the same way as nighttime respiration due to photo-inhibition of leaf respiration in the light, potentially resulting in an overestimate of respiration (Brooks and Farquhar 1985; Villar et al. 1994, but see also Loreto et al. 1999; Loreto et al. 2001 and Pinelli and Loreto 2003). Since this issue is not resolved, we refrained from applying a correction.

Following standard procedure of eddy covariance data treatment (Baldocchi 2003), we excluded data collected under conditions of low turbulence (friction velocity $u^{*}$ below a threshold value) or during rain (precipitation more than $0.1 \mathrm{~mm}$ per $30 \mathrm{~min}$ ), or containing unrealistic variance in the $\mathrm{CO}_{2}$ mixing ratio (variance $>3.5 \mathrm{ppm}$, equivalent to the top $2.5 \%$ of the observations), and calculated nighttime averages only if more than $2.5 \mathrm{~h}$ of valid data were available. This resulted in a data coverage of approximately $50 \%$ of all nights. With continuous eddy covariance measurements it is possible to estimate ecosystem respiration by fitting regression over shorter time windows as done in Knohl et al. (2003) or Reichstein et al. (2005). In this study we, however, intended to compare ecosystem respiration with sporadically measured soil respiration and 
therefore chose to use the same extrapolation approach for both processes and used in both cases a single regression over an entire year.

Uncertainty in ecosystem respiration can be caused by random errors, e.g. instrument noise, as well as systematic errors, e.g. loss of carbon dioxide via advection during night. Due to the large amount of data collected with the eddy covariance technique $(N>8,000$ per year), random errors are typically small (Baldocchi 2003; Morgenstern et al. 2004). In order to assess systematic error associated with data rejection criteria due to non-turbulent condition and advection, we decided to calculate ecosystem respiration for various data rejection criteria. To exclude data points of low turbulence, we used three different friction velocity threshold values reasonable for our site $(0.4,0.5$, and $\left.0.6 \mathrm{~m} \mathrm{~s}^{-1}\right)$. In each case we calculated annual ecosystem respiration based on soil temperature at $2 \mathrm{~cm}$, at $5 \mathrm{~cm}$, and on air temperature at $2 \mathrm{~m}$ resulting in nine different values for annual ecosystem respiration. We then report mean and range of all approaches.

\section{Results}

Soil respiration measured over 3 years showed a wide range of flux rates, from minimum averages of $0.5 \mu \mathrm{mol} \mathrm{CO} \mathrm{CO}^{-2} \mathrm{~s}^{-1}$ (winter) to maximum averages of about $6 \mu \mathrm{mol} \mathrm{CO} \mathrm{Cm}^{-2} \mathrm{~s}^{-1}$ (summer) for all the measurement locations (Fig. 1). Both soil and ecosystem respiration rates were highly related to soil temperature $\left(R_{\mathrm{S}}: r^{2}=0.67-0.96, N=9-15 ; R_{\mathrm{E}}: r^{2}=\right.$ $0.62-0.67, N=156-170$; Fig. 2 and Table 1). In the wet year 2000, a very strong relationship between soil respiration and soil temperature at $5 \mathrm{~cm}$ was found $\left(r^{2}=0.96, N=12\right)$. On the other hand in 2001, which had a distinct dry period in August (volumetric soil moisture $<23 \%$, equals approximately a soil water potential less than $-1.2 \mathrm{MPa}$ or a relative extractable soil water (Granier et al. 2007) of 0.35 at our given soil texture), the relationship between $R_{\mathrm{S}}$ and $T_{\text {soil, } 5 \mathrm{~cm}}$ was relatively weak $\left(r^{2}=0.67, N=15\right)$. When soil moisture was included in the model for soil respiration in 2001, the explanatory value of the model increased remarkably $\left(r^{2}=0.78, N=15\right.$ with the equation: $y=0.26$ $\left.e^{0.132 T} e^{0.024 \theta}\right)$. The influence of drought is further illustrated in the residual plot (Fig. 2, lower panel), where the respiration rates during the driest measurement campaigns were below the values expected from

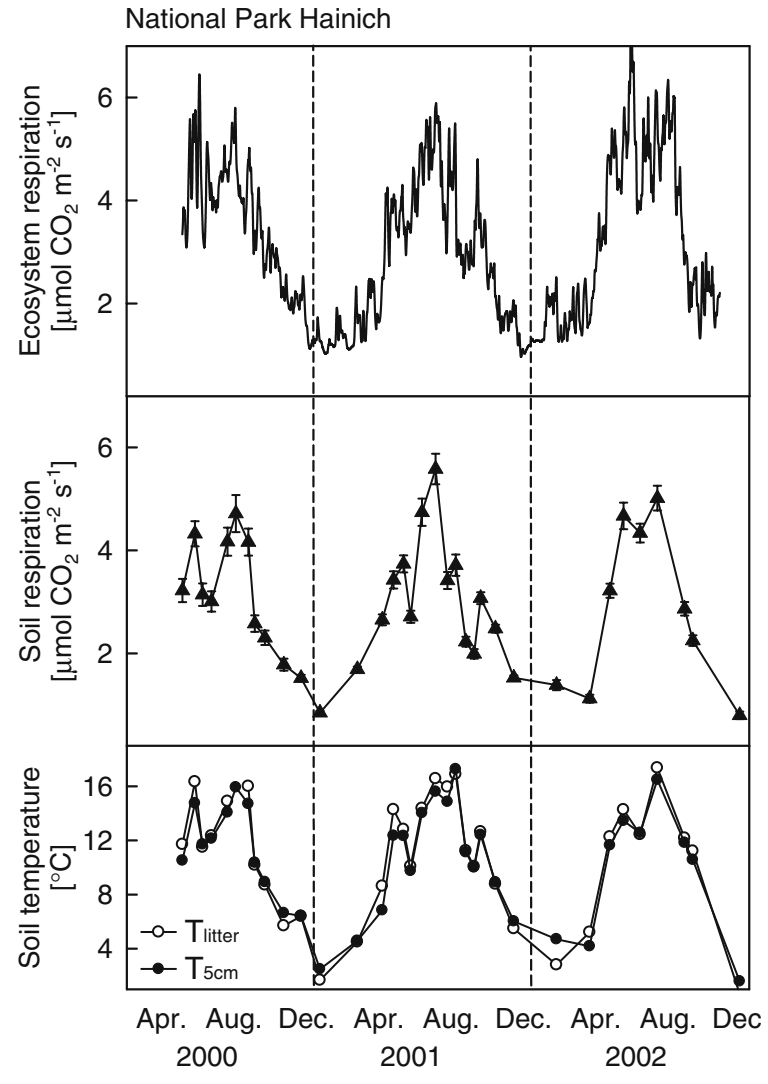

Fig. 1 Ecosystem respiration, soil respiration, and soil temperature over 3 years. Ecosystem respiration was estimated based on continuous nighttime eddy covariance measurements and extrapolation to daytime using Eq. 1. Soil respiration and soil temperature were measured at 10 plots with a total number of 36 collars during 35 campaigns. Error bars indicate standard error of the mean

the temperature regression in 2001. Furthermore, unusual high rates of ecosystem respiration were observed during the distinct periods of budbreak (Fig. 2, upper panel, A) in all 3 years and during leaffall in autumn 2001 (Fig. 2, upper panel, B).

While year to year variation of annual soil respiration was relatively small (see Table 2), spatial variation in the annual efflux of soil $\mathrm{CO}_{2}$ found among collars and plots at different distances from the flux tower was very pronounced. In order to test for spatial independence of our measurements we performed an analysis of variance and found that variances of soil respiration for collars within a plot (distance within $1 \mathrm{~m}$ ) was significantly lower than the variance among plots (ANOVA, $P<0.001,36$ collar, 10 plots) indicating a small scale spatial dependence. 
Fig. 2 Relationships between ecosystem respiration rates $\left(R_{\mathrm{E}}\right)$ and soil respiration rates $\left(R_{\mathrm{S}}\right)$ vs soil temperature (upper two panels, for $R_{\mathrm{E}}$ in 2000: $y=1.15$ $e^{0.103 T} ; 2001: y=1.15$ $e^{0.097 T} ; 2002: y=1.21$ $e^{0.101 T}$, for $R_{\mathrm{S}}$ in 2000 : $y=0.85 e^{0.109 T}$; 2001: $y=1.13 e^{0.085 T}$; 2002: $y=0.83 e^{0.115 T}$ ). Only nighttime data were used for the ecosystem respiration models to avoid influence of photosynthesis occurring during daytime. Relatively high ecosystem respiration rates (open triangles) were observed during budbreak $(A)$ and after leaffall $(B)$. The residuals from the regressions of soil respiration vs oil temperature are plotted in the lower panel against soil moisture
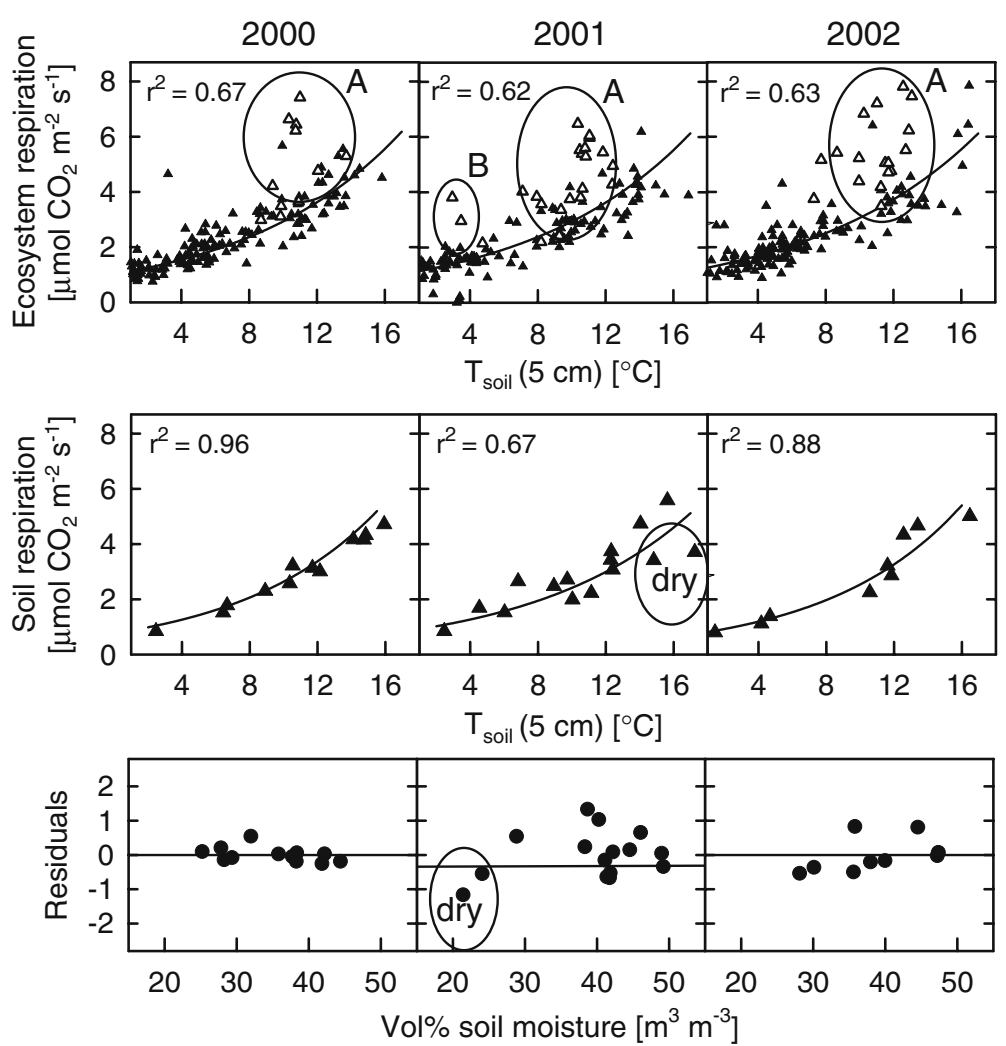

The effect of variability at very small spatial scale could have been reduced using larger collars that integrate over larger soil area. On the other hand our sampling design with a high number of sample location required a reliable but yet portable system. We therefore chose intermediate size collars $(10 \mathrm{~cm}$ diameter) to integrate over a sufficiently large soil area while remaining easily portable. In order to test further for dependence of soil respiration measure- ments among plots (30 m apart, large scale) we performed an autocorrelation test. No significant autocorrelation among plots was found $(P>0.16)$. This confirms findings by Soe and Buchmann (2005) who performed a geostatistical analysis of soil respiration measured with the same method on a $72 \times 72 \mathrm{~m}$ grid next to our transect and found - using a semivariogram - that soil respiration was spatially correlated only on a scale smaller than $6 \mathrm{~m}$ distances

Table 1 Regression coefficients for soil respiration and ecosystem respiration based on Eqs. 1 and 2

\begin{tabular}{llllr}
\hline Year & $k$ & $a$ & $b$ & $\mathrm{r}^{2}$ \\
\hline Soil respiration & & & & $N$ \\
2000 (Eq. 1) & $0.85 \pm 0.09$ & $0.109 \pm 0.007$ & - & 0.96 \\
2001 (Eq. 1) & $1.13 \pm 0.27$ & $0.085 \pm 0.018$ & - & 0.67 \\
2001 (Eq. 2) & $0.26 \pm 0.14$ & $0.132 \pm 0.021$ & $0.024 \pm 0.008$ & 0.78 \\
2002 (Eq. 1) & $0.83 \pm 0.21$ & $0.115 \pm 0.019$ & - & 0.88 \\
Ecosystem respiration & & & - & 15 \\
2000 (Eq. 1) & $1.15 \pm 0.08$ & $0.103 \pm 0.006$ & - & 0.67 \\
2001 (Eq. 1) & $1.15 \pm 0.09$ & $0.097 \pm 0.007$ & $0.024 \pm 0.004$ & 15 \\
2001 (Eq. 2) & $0.35 \pm 0.07$ & $0.124 \pm 0.007$ & - & 0.70 \\
2002 (Eq. 1) & $1.21 \pm 0.08$ & $0.101 \pm 0.006$ & 156 \\
\hline
\end{tabular}


Table 2 Contribution of soil respiration to total ecosystem respiration (given in brackets, e.g. $(=81 \%)$ )

\begin{tabular}{|c|c|c|c|c|c|}
\hline & $N$ plot/collar & 2000 (Eq. 1) & 2001 (Eq. 1) & 2001 (Eq. 2) & 2002 (Eq. 1) \\
\hline$R_{\mathrm{E}}\left[\mathrm{g} \mathrm{C} \mathrm{m}^{-2}\right.$ year $\left.^{-1}\right]$ & & $1,125[1,069,1,220]$ & $1,019[979,1,076]$ & $1,021[985,1,083]$ & $1,099[1,040,1,179]$ \\
\hline $\begin{array}{l}R_{\mathrm{S}}\left[\mathrm{g} \mathrm{C} \mathrm{m}^{-2} \text { year }^{-1}\right] \\
\text { plot } 1(0-50 \mathrm{~m})\end{array}$ & $1 / 5$ & $\begin{array}{l}1,153[1,040,1,230] \\
(=102 \%)\end{array}$ & $\begin{array}{l}1,144[922,1,281] \\
(=112 \%)\end{array}$ & $\begin{array}{l}1,245 \\
(=122 \%)\end{array}$ & $\begin{array}{l}1,078[714,1,243] \\
(=98 \%)\end{array}$ \\
\hline $\begin{array}{l}R_{\mathrm{S}}\left[\mathrm{g} \mathrm{C} \mathrm{m}^{-2} \text { year }^{-1}\right] \\
\text { plot } 1-10(0-300 \mathrm{~m})\end{array}$ & $10 / 36$ & $\begin{array}{l}908[857,942] \\
(=81 \%)\end{array}$ & $\begin{array}{l}891[844,928] \\
(=87 \%)\end{array}$ & $919(=90 \%)$ & $\begin{array}{l}896[834,941] \\
(=82 \%)\end{array}$ \\
\hline $\begin{array}{l}R_{\mathrm{S}}\left[\mathrm{g} \mathrm{C} \mathrm{m}^{-2} \text { year }^{-1}\right] \\
\quad \text { (footprint weighted) }\end{array}$ & $10 / 36$ & $\begin{array}{l}892[834,926] \\
(=79 \%)\end{array}$ & $\begin{array}{l}870[822,907] \\
(=85 \%)\end{array}$ & $897(88 \%)$ & $\begin{array}{l}876[816,926] \\
(=80 \%)\end{array}$ \\
\hline
\end{tabular}

Soil respiration $\left(R_{\mathrm{S}}\right)$ was estimated using three different subsets of soil respiration measurement plots (only plot close to tower, all plots, all plots weighted by footprint function; mean and [95\% confidence intervals] are given); ecosystem respiration $\left(R_{\mathrm{E}}\right)$ was estimated using a range of data filtering criteria (see text, mean and [range] are given). $N$ is the number of plots and collars within each subset

(for more details see Søe 2003). We therefore treated measurements from collars within one single plot (three to five collars) as dependent (and hence averaged them before further analysis) and the mean of each plot as spatially independent (10 plots). Spatial variation along the transect was high and consistent over the years (Fig. 3). In general, plots with high soil $\mathrm{CO}_{2}$ efflux rates (e.g. the closest and the farthest plots) had high efflux rates during all 3 years, whereas those plots in the middle of the transect had lower rates over the same period. Fine root biomass sampled at each plot explained 56\% (significant at $5 \%$ level) of the spatial variance in annual soil respiration (Fig. 4).

The precision of annual soil efflux estimates depended on the number of spatially independent

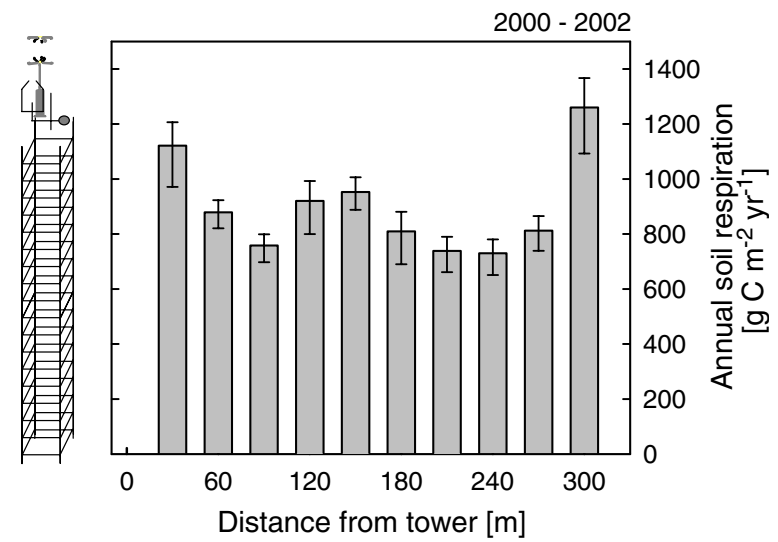

Fig. 3 Average annual soil respiration $\left(R_{\mathrm{S}}\right)$ measured in plots along a transect in the main source area (south-east) at different distances from the eddy covariance tower during the 3 years, 2000,2001 , and 2002 ( $N$ for each plot: 3-5, error bars indicate $95 \%$ confidence intervals around the mean flux over the 3 years) samples used (Table 3). At a 95\% confidence level, measurements from $4 \pm 1$ random locations along the transect in the source area of the tower were needed to obtain an estimate that was within $30 \%$ of the full population mean. Increasing the precision of the estimate meant increasing the number of measuring points. Thus, for $20 \%$ precision, $8 \pm 1$ locations were needed, and to reach $10 \%$ precision, $34 \pm 5$ locations should have been measured. These numbers are average values for all measurement campaigns over 3 years. Typically, more measurements were needed in winter when soil respiration fluxes are small and hence the ratio of standard deviation to desired range of precision is large (dependent on mean soil respiration flux; see Eq. 3). However, for the annual soil respiration estimate, the lower precision of winter time flux played only a minor role since fluxes were

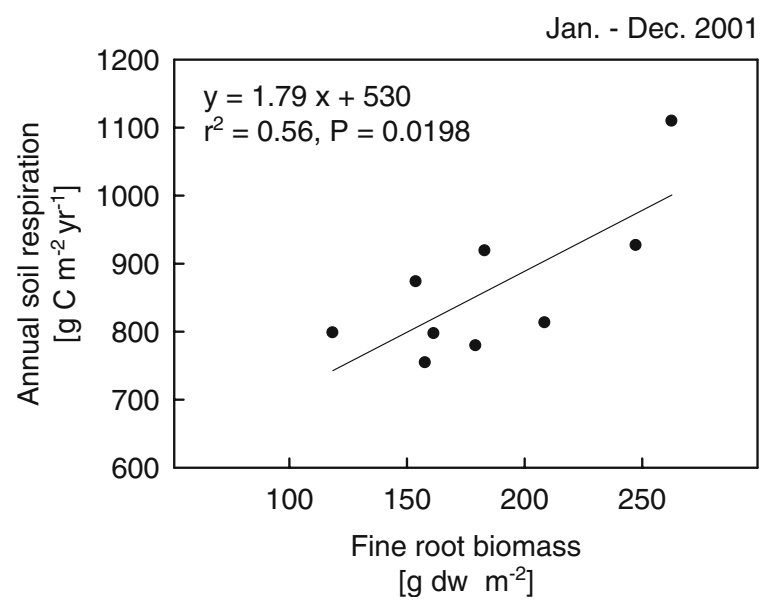

Fig. 4 Relationship between annual soil respiration and dry weight of fine root biomass measured at individual plots. Data are from 2001 
Table 3 Required number of soil respiration measurement locations to achieve a precision of $\pm 10, \pm 20$, or $\pm 30 \%$ around full population mean at various confidence levels (80-99\%)

\begin{tabular}{lllll}
\hline $\begin{array}{l}\text { Interval } \\
\text { around full } \\
\text { population } \\
\text { mean [\%] }\end{array}$ & $\begin{array}{l}99 \% \\
\text { confidence }\end{array}$ & $\begin{array}{l}95 \% \\
\text { confidence }\end{array}$ & $\begin{array}{l}90 \% \\
\text { confidence }\end{array}$ & $\begin{array}{l}80 \% \\
\text { confidence }\end{array}$ \\
\hline \pm 10 & $70 \pm 9$ & $34 \pm 5$ & $22 \pm 3$ & $12 \pm 2$ \\
\pm 20 & $17 \pm 2$ & $8 \pm 1$ & $6 \pm 1$ & $3 \pm 0$ \\
\pm 30 & $8 \pm 1$ & $4 \pm 1$ & $2 \pm 0$ & $1 \pm 0$ \\
\hline
\end{tabular}

Calculations are based on a population of 10 measurement plots in the National Park Hainich sampled during 35 campaigns in 2000, 2001 and 2002. Averages and standard errors are given.

very small. More importantly, during summer when the ratio of standard deviation to desired range of precision is small due to high soil respiration fluxes, fewer measurements were needed.

\section{Discussion}

Modelling respiration rates

Temporal variation among soil and ecosystem respiration rates in our study $\left(0.5-6 \mu \mathrm{mol} \mathrm{CO} \mathrm{CO}_{2} \mathrm{~m}^{-2}\right)$ was well described by simple exponential functions (temperature only) when favorable conditions were the rule, such as in the wet year 2000. However, under dry conditions, such as in the summer 2001, a model with only soil temperature explained much less of the variation in soil respiration rates $(67 \%)$ than a model that also included soil moisture (78\%). Davidson et al. (1998) proposed a similar model for a North American hardwood forest. In their study, the precision of the estimate increased considerably when soil moisture was included. We found that low soil water conditions began to be limiting at about $23 \%$ soil water content which equals approximate $-1.2 \mathrm{MPa}$ soil water potential or 0.35 relative plant available soil water. We suspect that the high clay content ( $40 \%$ by mass) limited the availability of water to plants and microorganisms during dry soil conditions. A similar strong effect of soil moisture was observed on the ecosystem respiration (Knohl et al. 2003) and compares well with findings from other European forest sites (Granier et al. 2007). A potential decrease in soil respiration at high soil water content (supra saturation) - as seen in other sites (Subke et al. 2003) - was not detected in our data due to fairly long intervals between measurements and typically not directly after rain. If soil respiration declines at supra saturation then we would expect to overestimate annual soil respiration. Overall, our results support conclusion of Janssens et al. (2003): even in ecosystems where drought limits soil respiration only occasionally, it is recommended to use a soil respiration model that includes both soil moisture and soil temperature.

Temporal and spatial variation of respiration rates

Soil respiration measured in the main source area of the eddy covariance tower (footprint weighted) constituted $79-88 \%$ of the total ecosystem respiration (Table 2), which is at the upper end, but within the range of values reported earlier (Law et al. 1999; Pilegaard et al. 2001; Janssens et al. 2001; Shibistova et al. 2002). Davidson et al. (2006) reported for a coniferous forest seasonal variation in the ratio of soil respiration to ecosystem respiration with a minimum in spring (45\%) and a maximum in fall (80\%). Soil respiration rates from plots 30 and $300 \mathrm{~m}$ away from the tower were more than $50 \%$ higher than those 90 , 210, and $240 \mathrm{~m}$ away (Fig. 3). A large part of the variance in soil respiration $(56 \%)$ was explained by fine root biomass. In a detailed associated study on a nearby located $72 \times 72 \mathrm{~m}$ grid (100 m away), Soe and Buchmann (2005) showed that - along with fine root biomass - other factors such as stand structure (diameter at breast height of trees within $4 \mathrm{~m}$ ), soil carbon content and soil water content play an important role in explaining spatial variability. Combining these four factors explained $79 \%$ of the observed variance at the $72 \times 72 \mathrm{~m}$ grid. Soil respiration consists of heterotrophic respiration from microbial activity and of autotrophic respiration from active plant biomass. An increase in fine root biomass implies an addition of autotrophic respiration to a base line of heterotrophic respiration. If no other processes were present, then the y-intercept of Fig. 4 should represent heterotrophic respiration alone. There are, however, interactions between heterotrophic and autotrophic respiration that prevent a linear extrapolation such as the priming effect, i.e. a stimulation or suppression of heterotrophic respiration through the presents of plant exudates or fresh litter (Bader and Cheng 2007; Helal and Sauerbeck 1984; 
Reid and Goss 1982), and respiration from mycorrhiza (Zhu and Miller 2003).

Similarly high spatial variability from plot to plot within a forest was shown by Buchmann (2000), Davidson et al. (1998) and Xu and Qi (2001). When soil respiration was measured only at the five locations closest to the tower - as often done at flux sites due to logistical reasons - soil respiration was estimated to contribute between 98 and $122 \%$ of total ecosystem respiration. Since ecosystem respiration is composed of soil respiration as well as leaf, branch, and stem respiration, a soil respiration contribution above $100 \%$ is unrealistic. In our case, such high contributions reflected the unrepresentative stand structure directly next to the tower, i.e. tall and old trees, compared to the entire source area. Therefore, in a heterogeneous ecosystem, the location of measurements has great significance for the measured flux rates and thus estimates of annual soil respiration rates. Extremely high or low estimates may be detected when comparisons are made to the spatially integrating ecosystem respiration measured by the micrometeorological eddy covariance method.

At the ecosystem level, we observed higher than expected respiration rates during spring and fall, which are probably connected to higher physiological activity at budbreak (during April and May) and increased respiration after leaf fall (mainly October; see also Knohl et al. 2003). Increased leaf respiration during leaf expansion is well known from leaf level measurements (Schulze 1970). Also, such phenological effects were reported from a study of soil respiration in a Danish beech forest (Pilegaard et al. 2001), indicating the limitation of sporadically made soil respiration measurements. DeForest et al. (2006) and Yuste et al. (2004) hence suggest to include phenology and plant activity into soil respiration models. Since our soil respiration measurements were only periodically, these pulse-like effects were not detected in the soil respiration measurements.

\section{Potential biases of both measurement systems}

Timing of data collection represents a very critical factor for both measurement systems. For portable chamber systems, measurements are normally carried out during daytime hours; for the eddy covariance system on the other hand, only nighttime measurements truly reflect ecosystem respiration since daytime measurements integrate respiration and photosynthesis. If there are large differences between day and night fluxes (e.g. high flux rate during daytime, which cannot be explained by soil temperature alone), diurnal extrapolations of data may lead to significant biases. Such diurnal patterns in respiration (not caused by temperature) have been reported, for example, from studies in a wheat field and in North American forests (Davidson et al. 1998, Kuzyakov and Cheng 2001; Liu et al. 2006). Especially in the wheat field, the diurnal pattern of soil respiration was rather strong, independent of temperature, most likely due to recent photosynthates being respired within a few hours after assimilation. At our study site, no significant differences (independent of soil temperature) were detected between day and night soil efflux rates (diurnal cycle were measured in summer 2000 and 2002, data not shown). Results from a study by Buchmann (2000) in a Central German coniferous forest support our findings: although small diurnal patterns were observed, these were completely explained by changes in soil temperature. Nevertheless, plant-soil interactions due to plant ecophysiology may be more critical in other ecosystems (Hogberg and Read 2006; Larsen et al. 2007).

Upscaling from just a few measurements over the course of the year $(N=9-15)$ to an annual sum will increase uncertainty of the final estimate. Bootstrapping indicated that the $95 \%$ confidence intervals of annual sums were typically -130 to $+80 \mathrm{~g} \mathrm{C} \mathrm{m}^{-2}$ year $^{-1}$ around the mean, asymmetrical due to the non-linear response of soil respiration to temperature. Parkin and Kaspar (2004) showed with automated continuous soil respiration measurements and statistical analysis (numerically simulating a coarser time resolution) that an increase in measurement frequency, i.e., a reduction in the time interval between measurements from 20 to 3 days, would decrease uncertainty by more than $50 \%$. In our setting, however, a measurement frequency of 3 days at 36 locations would not have been feasible.

The eddy covariance method, on the other hand, may underestimate nighttime ecosystem respiration due to carbon dioxide loss during calm periods when horizontal advection occurs along the slope of the terrain, which can cause substantial uncertainty in annual flux rates (Loescher et al. 2006). Advection has been proven to exist at this site, but can not be estimated very accurately (yet; Kutsch et al. 2007). Significant advection and hence underestimation of ecosystem 
respiration could also contribute to our observed high ratios of soil to ecosystem respiration. Situations where soil respiration from chamber measurements were higher than ecosystem respiration from eddy covariance measurements were also observed at other sites (Wayson et al. 2006). In order to minimize the effect of advection, we applied a so-called $u_{*}$-correction where all data with a friction velocity $(u *)$ under a certain threshold are excluded and replaced by a regression model based on the remaining data (for details see Knohl et al. 2003 and Kutsch et al. 2007). Our sensitivity analysis with various $\mathrm{u}_{*}$-thresholds and different regression models (using soil temperature in $2 \mathrm{~cm}$, in $5 \mathrm{~cm}$ and canopy air temperature) indicated a range of about -50 to $+80 \mathrm{~g} \mathrm{C} \mathrm{m}^{-2}$ year $^{-1}$ around the mean.

Ideally, measurements as at our site would be complemented by continuous soil respiration measurements using automated chambers (e.g. Drewitt et al. 2002; Savage and Davidson 2003; Subke et al. 2003; Wayson et al. 2006) or continuous measurements of soil $\mathrm{CO}_{2}$ concentration profiles from which soil respiration can be calculated if soil physical parameters are known for a broad range of environmental conditions (Tang et al. 2003).

Annual estimates of soil respiration in heterogeneous sites - problems and recommendations

The high degree of spatial variability at our study site clearly created a challenge for precise annual upscaling of soil respiration chamber measurements. When soil respiration was weighted with the source weight function from the footprint model, the annual soil $\mathrm{CO}_{2}$ efflux was estimated as 870 to $897 \mathrm{~g} \mathrm{C} \mathrm{m}^{-2}$ year $^{-1}$, which was very similar to the average estimate across all plots without weighting (Table 2). There are, however, limitations in scaling soil respiration according to a footprint model. First, the real footprint of eddy covariance flux measurements is two-dimensional including all wind directions, while our soil respiration measurements where only along one transect within the dominant wind direction. Second, nighttime footprints can - depending on atmospheric stratification - extend over several kilometers, well beyond a feasible distance for regular intensive soil respiration measurements. Nevertheless, even an only $300 \mathrm{~m}$ long transect does provide a reasonable estimate of spatial variability, but will clearly not cover the same source area of the ecosystem respiration measurements. If we had taken measurements in only the five locations closest to the tower $(0-50 \mathrm{~m})$, the annual efflux would have been estimated as 1,078 to $1,245 \mathrm{~g} \mathrm{C} \mathrm{m}^{-2}$ year $^{-1}$, which is an overestimation of more than $30 \%$ compared to the footprint weighted estimate. In a very heterogeneous boreal forest site with obvious patches of closed canopy and patches of open vegetation, soil respiration rates in open areas were only $50 \%$ of the rates under dense canopy (Shibistova et al. 2002). To take this site heterogeneity into account, they employed a stratified measurement scheme, choosing a representative number of locations under dense canopy and in open areas, reflecting the coverage for each of the two vegetation types. A similar stratification approach was carried out by Davidson et al. (1998) who classified areas with high and low soil respiration rates according to soil moisture. However, at our study site, areas of high or low respiration rates were not so easy to identify, since the canopy was dense all along the transect within the source area of the tower, and the soil moisture was relatively constant from location to location. Fine root biomass - reflecting stand density - explained most of the spatial variation but was not directly deducible without soil coring.

A large number of measurement locations is ideal for evaluating soil respiration, but logistical constraints on labor and time often limit the feasibility of such an approach. Davidson et al. (2002) presented some helpful calculations for identifying the number of randomly located measurements needed in a tropical grassland to obtain certain levels of precision for their soil respiration estimate. They showed that for a $95 \%$ probability level, 41 measurements locations were needed to give an estimate within $\pm 10 \%$ of the full population mean; 10 measurements locations were needed to give an estimate within $\pm 20 \%$; and five measurements locations were needed to give an estimate within $\pm 30 \%$. Similarly, in a Japanese larch plantation 27-33 measurement locations were needed in order to stay within $10 \%$ of the population mean, and 7-8 locations to stay within $20 \%$ of the populations mean (Yim et al. 2002). Based on our study, we recommend to stay within $20 \%$ of the full population mean of soil respiration and to measure at least eight measurement locations (equal to $\pm 20 \%$ precision at $95 \%$ confidence), spaced randomly in the area of interest, for example, the source area of an eddy covariance tower. Further, we recommend 
installing measurements collars sufficiently apart in order to obtain statistically independent samples. At our site samples were spatially dependent on a scale smaller than $6 \mathrm{~m}$ distances (Soe and Buchmann 2005) and we therefore only used the averages from our 10 plots (30 $\mathrm{m}$ apart) for this analysis. The exact number of measurement locations needed to attain a given level of precision will be site-specific: for sites with large spatial variation in soil respiration rates, the number of measurement locations needed for any level of precision will be larger than for homogeneous sites.

\section{Conclusion}

In this study we showed that soil respiration contributed to a large part to ecosystem respiration and that spatial variability of soil respiration at our site was high and strongly related to fine root biomass. Based on our extensive spatial sampling and a statistical analysis we estimated that at least eight measurement locations were needed to stay within $\pm 20 \%$ of the expected mean at $95 \%$ confidence. The results of our study point to a two-step approach if the soil respiration estimate serves as basis for a reliable carbon budget in heterogeneous forests. In the first step, spatial variability should be captured with several intensive measurement campaigns during the first year (using about 40-50 measurement locations). Based on this knowledge and on the selection of precision and confidence levels, a representative subset of plots should be selected, where more frequent chamber measurements are performed in subsequent years to capture the temporal variability. Obtaining reliable annual estimates of soil respiration, capturing their temporal variability, and assessing their associated uncertainties will become increasingly important, since extensive droughts - as experienced in Europe over the last years and anticipated in the futureled to fairly rapid modifications in soil and ecosystem respiration over the summer months (Ciais et al. 2005, Reichstein et al. 2007). Thus, the results of our study might be useful to develop a standard protocol across sites, which can easily be adapted to site-specific conditions. Within large-scale projects, continental or even global networks such as CarboEurope or FLUXNET, such clear recommendations on how to improve the precision of soil respiration estimates would add further confidence to the overall carbon budgets.
Acknowledgements We would like to thank a number of colleagues for their support: Karin Sörgel, Waldemar Ziegler, Kim Pilegaard, Olaf Kolle, Andreas Ricklinkat, Juliane Anders, and Karin Zuber. We acknowledge helpful support on statistical questions from Jens Schumacher and Cornelius Middelhoff. We thank the administration from the National Park Hainich for their kind cooperation. This project was supported by the Max Planck Society and the EU-project CarboEuroflux under number EVK2CT-1999-00032. AK was funded by the EU with a Marie Curie fellowship under Contract no MOIF-CT-2004-002543.

\section{References}

Bader NE, Cheng WX (2007) Rhizosphere priming effect of Populus fremontii obscures the temperature sensitivity of soil organic carbon respiration. Soil Biol Biochem 39:600-606

Baldocchi DD (2003) Assessing the eddy covariance technique for evaluating carbon dioxide exchange rates of ecosystems: past, present and future. Glob Change Biol 9:479-492

Brooks A, Farquhar GD (1985) Effect of temperature on the $\mathrm{CO} 2 / \mathrm{O} 2$ specificity of ribulose-1,5-bisphosphate carboxylase oxygenase and the rate of respiration in the lightestimates from gas-exchange measurements on spinach. Planta 165:397-406

Buchmann N (2000) Biotic and abiotic factors controlling soil respiration rates in Picea abies stands. Soil Biol Biochem 32:1625-1635

Ciais P, Reichstein M, Viovy N, Granier A, Ogee J, Allard V, Aubinet M, Buchmann N, Bernhofer C, Carrara A, Chevallier F, De Noblet N, Friend AD, Friedlingstein P, Grunwald T, Heinesch B, Keronen P, Knohl A, Krinner G, Loustau D, Manca G, Matteucci G, Miglietta F, Ourcival JM, Papale D, Pilegaard K, Rambal S, Seufert G, Soussana JF, Sanz MJ, Schulze ED, Vesala T, Valentini R (2005) Europewide reduction in primary productivity caused by the heat and drought in 2003. Nature 437:529-533

Crawley MJ (2002) Statistical computing. Wiley and Sons, Chichester

Davidson EA, Belk E, Boone RD (1998) Soil water content and temperature as independent or confounded factors controlling soil respiration in a temperate mixed hardwood forest. Glob Change Biol 4:217-227

Davidson EA, Savage K, Verchot LV, Navarro R (2002) Minimizing artifacts and biases in chamber-based measurements of soil respiration. Agric For Meteorol 113:21-37

Davidson EA, Richardson AD, Savage KE, Hollinger DY (2006) A distinct seasonal pattern of the ratio of soil respiration to total ecosystem respiration in a sprucedominated forest. Glob Change Biol 12:230-239

DeForest JL, Noormets A, McNulty SG, Sun G, Tenney G, Chen JQ (2006) Phenophases alter the soil respirationtemperature relationship in an oak-dominated forest. Int $\mathrm{J}$ Biometeorol 51:135-144

Drewitt GB, Black TA, Nesic Z, Humphreys ER, Jork EM, Swanson R, Ethier GJ, Griffis T, Morgenstern K (2002) Measuring forest floor $\mathrm{CO} 2$ fluxes in a Douglas-fir forest. Agric For Meteorol 110:299-317

Gockede M, Markkanen T, Mauder M, Arnold K, Leps JP, Foken $T$ (2005) Validation of footprint models using 
natural tracer measurements from a field experiment. Agric For Meteorol 135:314-325

Goulden ML, Munger JW, Fan S-M, Daube BC, Wolsy SC (1996) Measurements of carbon sequestration by longterm eddy covariane: methods and a critical evaluation of accuracy. Glob Change Biol 2:169-182

Granier A, Reichstein M, Breda N, Janssens IA, Falge E, Ciais P, Grunwald T, Aubinet M, Berbigier P, Bernhofer C, Buchmann N, Facini O, Grassi G, Heinesch B, Ilvesniemi H, Keronen P, Knohl A, Kostner B, Lagergren F, Lindroth A, Longdoz B, Loustau D, Mateus J, Montagnani L, Nys C, Moors E, Papale D, Peiffer M, Pilegaard K, Pita G, Pumpanen J, Rambal S, Rebmann C, Rodrigues A, Seufert G, Tenhunen J, Vesala T, Wang Q (2007) Evidence for soil water control on carbon and water dynamics in European forests during the extremely dry year: 2003. Agric For Meteorol 143:123-145

Helal HM, Sauerbeck DR (1984) Influence of plant-roots on C and $\mathrm{P}$ metabolism in soil. Plant Soil 76:175-182

Hogberg P, Read DJ (2006) Towards a more plant physiological perspective on soil ecology. Trends Ecol Evol 21:548-554

Hutchinson GL, Livingston GP (2002) Soil-atmosphere gas exchange. In: Dane JH, Topp GC (eds) Methods of soil analysis: part 4, physical methods. Soil Science Society of America, Madison, USA, pp 1159-1182

Janssens IA, Lankreijer H, Matteucci G, Kowalski AS, Buchmann N, Epron D, Pilegaard K, Kutsch W, Longdoz B, Grunwald T, Montagnani L, Dore S, Rebmann C, Moors EJ, Grelle A, Rannik U, Morgenstern K, Oltchev S, Clement R, Gudmundsson J, Minerbi S, Berbigier P, Ibrom A, Moncrieff J, Aubinet M, Bernhofer C, Jensen NO, Vesala T, Granier A, Schulze ED, Lindroth A, Dolman AJ, Jarvis PG, Ceulemans R, Valentini R (2001) Productivity overshadows temperature in determining soil and ecosystem respiration across European forests. Glob Change Biol 7:269-278

Janssens IA, Dore S, Epron D, Lankreijer H, Buchmann N, Longdoz B, Brossaud J, Montagnani L (2003) Climatic influences on seasonal and spatial differences in soil $\mathrm{CO} 2$ efflux. In: Valentini R (ed) Fluxes of carbon, water and energy of European forests. Springer, Berlin, p 270

Knohl A, Schulze E-D, Kolle O, Buchmann N (2003) Large carbon uptake by an unmanaged 250-year-old deciduous forest in Central Germany. Agric For Meteorol 118:151-167

Kutsch WL, Kolle O, Rebmann C, Knohl A, Ziegler W, Schulze E-D (2007) Process modelling and direct measurements of advection reveal uncertainties in flux measurements above a tall forest. Ecol. Appl (in press)

Kuzyakov Y, Cheng W (2001) Photosynthesis controls of rhizosphere respiration and organic matter decomposition. Soil Biol Biochem 33:1915-1925

Larsen KS, Ibrom A, Beier C, Jonasson S, Michelsen A (2007) Ecosystem respiration depends strongly on photosynthesis in a temperate heath. Biogeochemistry 85:201-213

Law BE, Ryan MG, Anthoni PM (1999) Seasonal and annual respiration of a ponderosa pine ecosystem. Glob Change Biol 5:169-182

Liu Q, Edwards NT, Post WM, Gu L, Ledford J, Lenhart S (2006) Temperature-independent diel variation in soil respiration observed from a temperate deciduous forest. Glob Change Biol 12:2136-2145
Lloyd J, Taylor JA (1994) On the temperature dependence of soil respiration. Funct Ecol 8:315-323

Loescher HW, Law BE, Mahrt L, Hollinger DY, Campbell J, Wofsy SC (2006) Uncertainties in, and interpretation of, carbon flux estimates using the eddy covariance technique. J Geophys Res-Atmos 111, Art. No. D21S90

Loreto F, Delfine S, Di Marco G (1999) Estimation of photorespiratory carbon dioxide recycling during photosynthesis. Aust J Plant Physiol 26:733-736

Loreto F, Velikova V, Di Marco G (2001) Respiration in the light measured by (CO2)-C-12 emission in (CO2)-C-13 atmosphere in maize leaves. Aust J Plant Physiol 28:1103-1108

Morgenstern K, Black TA, Humphreys ER, Griffis TJ, Drewitt GB, Cai TB, Nesic Z, Spittlehouse DL, Livingstone NJ (2004) Sensitivity and uncertainty of the carbon balance of a Pacific Northwest Douglas-fir forest during an El Nino La Nina cycle. Agric For Meteorol 123:201-219

Parkin TB, Kaspar TC (2004) Temporal variability of soil carbon dioxide flux: Effect of sampling frequency on cumulative carbon loss estimation. Soil Sci Soc Am J 68:1234-1241

Pilegaard K, Hummelshoj P, Jensen NO, Chen Z (2001) Two years of continuous $\mathrm{CO} 2$ eddy-flux measurements over a Danish beech forest. Agric For Meteorol 107:29-41

Pinelli P, Loreto F (2003) (CO2)-C-12 emission from different metabolic pathways measured in illuminated and darkened C-3 and C-4 leaves at low, atmospheric and elevated CO2 concentration. J Exp Bot 54:1761-1769

Pumpanen J, Ilvesniemi H, Peramaki M, Hari P (2003) Seasonal patterns of soil $\mathrm{CO} 2$ efflux and soil air $\mathrm{CO} 2$ concentration in a Scots pine forest: comparison of two chamber techniques. Glob Change Biol 9:371-382

Pumpanen J, Kolari P, Ilvesniemi H, Minkkinen K, Vesala T, Niinisto S, Lohila A, Larmola T, Morero M, Pihlatie M, Janssens I, Yuste JC, Grunzweig JM, Reth S, Subke JA, Savage K, Kutsch W, Ostreng G, Ziegler W, Anthoni P, Lindroth A, Hari P (2004) Comparison of different chamber techniques for measuring soil $\mathrm{CO} 2$ efflux. Agric For Meteorol 123:159-176

Rannik U, Markkanen T, Raittila J, Hari P, Vesala T (2003) Turbulence statistics inside and over forest: Influence on footprint prediction. Bound-Layer Meteor 109:163-189

Reichstein M, Rey A, Freibauer A, Tenhunen J, Valentini R, Banza J, Casals P, Cheng YF, Grunzweig JM, Irvine J, Joffre R, Law BE, Loustau D, Miglietta F, Oechel W, Ourcival JM, Pereira JS, Peressotti A, Ponti F, Qi Y, Rambal S, Rayment M, Romanya J, Rossi F, Tedeschi V, Tirone G, Xu M, Yakir D (2003) Modeling temporal and large-scale spatial variability of soil respiration from soil water availability, temperature and vegetation productivity indices. Glob Biogeochem Cycle 17:Art. No. 1104

Reichstein M, Falge E, Baldocchi D, Papale D, Aubinet M, Berbigier P, Bernhofer C, Buchmann N, Gilmanov T, Granier A, Grunwald T, Havrankova K, Ilvesniemi H, Janous D, Knohl A, Laurila T, Lohila A, Loustau D, Matteucci G, Meyers T, Miglietta F, Ourcival JM, Pumpanen J, Rambal S, Rotenberg E, Sanz M, Tenhunen J, Seufert G, Vaccari F, Vesala T, Yakir D, Valentini R (2005) On the separation of net ecosystem exchange into assimilation and ecosystem respiration: review and improved algorithm. Glob Change Biol 11:1424-1439 
Reichstein M, Ciais P, Papale D, Valentini R, Running S, Viovy N, Cramer W, Granier A, Ogée J, Allard V, Aubinet M, Bernhofer Chr, Buchmann N, Carrara A, Grünwald T, Heimann M, Heinesch B, Knohl A, Kutsch W, Loustau D, Manca G, Matteucci G, Miglietta F, Ourcival JM, Pilegaard K, Pumpanen J, Rambal S, Schaphoff S, Seufert G, Soussana J-F, Sanz M-J, Vesala T, Zhao M (2007) Reduction of ecosystem productivity and respiration during the European summer 2003 climate anomaly: a joint flux tower, remote sensing and modelling analysis. Glob Change Biol 13(3):634-651. DOI 10.1111/j.13652486.2006.01224.x

Reid JB, Goss MJ (1982) Suppression of decomposition of C14-labeled plant-roots in the presence of living roots of maize and perennial ryegrass. J Soil Sci 33:387-395

Rey A, Pegoraro E, Tedeschi V, De Parri I, Jarvis PG, Valentini R (2002) Annual variation in soil respiration and its components in a coppice oak forest in Central Italy. Glob Change Biol 8:851-866

Savage KE, Davidson EA (2003) A comparison of manual and automated systems for soil $\mathrm{CO} 2$ flux measurements: tradeoffs between spatial and temporal resolution. J Exp Bot 54:891-899

Schulze E-D (1970) Der CO2-Gaswechsel der Buche (Fagus silvatica L.) in Abhaengigkeit von den Klimafaktoren im Freiland. Flora 159:177-232

Shibistova O, Lloyd J, Evgrafova S, Savushkina N, Zrazhewskaya G, Arneth A, Knohl A, Kolle O, Schulze E-D (2002) Seasonal and spatial variability in soil $\mathrm{CO} 2$ efflux rates for a central Siberian Pinus Sylvestris forest. Tellus Ser B-Chem Phys Meteorol 54B:552-567

Søe ARB (2003) Controlling factors, scaling issues and partitioning of soil respiration. In Biologisch-Pharmazeutischen Fakultät. Friedrich Schiller University, Jena, p 99

Soe ARB, Buchmann N (2005) Spatial and temporal variations in soil respiration in relation to stand structure and soil parameters in an unmanaged beech forest. Tree Physiol 25:1427-1436

Subke JA, Reichstein M, Tenhunen JD (2003) Explaining temporal variation in soil $\mathrm{CO} 2$ efflux in a mature spruce forest in Southern Germany. Soil Biol Biochem 35:1467-1483
Tang J, Baldocchi DD, Qi Y, Xu L (2003) Assessing soil CO2 efflux using continuous measurements of $\mathrm{CO} 2$ profiles in soils with small solid-state sensors. Agric For Meteorol 118:207-220

Thomson DJ (1987) Criteria for the selection of stochasticmodels of particle trajectories in turbulent flows. J Fluid Mech 180:529-556

Valentini R, Matteucci G, Dolman AJ, Schulze ED, Rebmann C, Moors EJ, Granier A, Gross P, Jensen NO, Pilegaard K, Lindroth A, Grelle A, Bernhofer C, Grunwald T, Aubinet M, Ceulemans R, Kowalski AS, Vesala T, Rannik U, Berbigier P, Loustau D, Guomundsson J, Thorgeirsson H, Ibrom A, Morgenstern K, Clement R, Moncrieff J, Montagnani L, Minerbi S, Jarvis PG (2000) Respiration as the main determinant of carbon balance in European forests. Nature 404:861-865

Villar R, Held AA, Merino J (1994) Comparison of methods to estimate dark respiration in the light in leaves of 2 woody species. Plant Physiol 105:167-172

Wayson CA, Randolph JC, Hanson PJ, Grimmond CSB, Schmid HP (2006) Comparison of soil respiration methods in a mid-latitude deciduous forest. Biogeochemistry 80:173-189

Wilson JD, Legg BJ, Thomson DJ (1983) Calculation of particle trajectories in the presence of a gradient in turbulentvelocity variance. Bound-Layer Meteor 27:163-169

Xu M, Qi Y (2001) Soil-surface CO2 efflux and its spatial and temporal variations in a young ponderosa pine plantation in northern California. Glob Change Biol 7:667-677

Yim MH, Joo SJ, Nakane K (2002) Comparison of field methods for measuring soil respiration: a static alkali absorption method and two dynamic closed chamber methods. For Ecol Manage 170:189-197

Yuste JC, Janssens IA, Carrara A, Ceulemans R (2004) Annual $\mathrm{Q}(10)$ of soil respiration reflects plant phenological patterns as well as temperature sensitivity. Glob Change Biol 10:161-169

Zhu YG, Miller RM (2003) Carbon cycling by arbuscular mycorrhizal fungi in soil-plant systems. Trends Plant Sci 8:407-409 